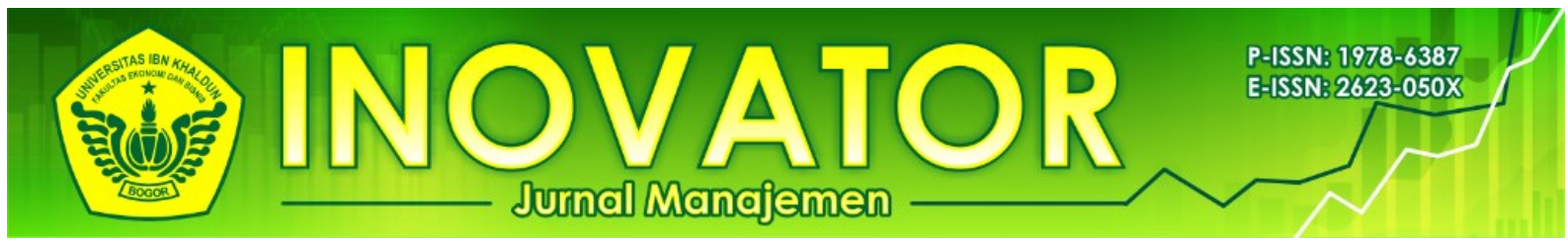

\title{
Kepuasan Pelanggan pada Produk Inovasi Pandemi COVID-19: Studi Kasus pada Contactless Delivery KFC Indonesia
}

\author{
Fairuz Calista N.F., Zuniar Risanti Pratiwi, Tasqia Angelina Purnama, dan Novika \\ Grasiaswaty
}

Fakultas Psikologi Universitas YARSI

Jl. Letjen Suprapto, Cempaka Putih, 10510, Jakarta

\begin{abstract}
Info Artikel
Kata Kunci:

COVID-19; Kepuasan pelanggan; Pandemi; dan Pengiriman nirsentuh; Kepuasan pelanggan

ISSN (print): 1978-6387

ISSN (online): 2623-050X

Penelitian ini mengenai evaluasi kepuasan pelanggan terhadap produk inovasi selama pandemi Covid-19 yaitu contactless delivery yang dilakukan oleh KFC Indonesia. Penelitian menggunakan mix-method dengan pendekatan kuantitatif dan kualitatif. Pengambilan data menggunakan tiga buah sudut pandang: kuesioner terhadap konsumen yang pernah menggunakan produk ini, wawancara mendalam terhadap pelanggan serta evaluasi terhadap iklan digital terkait produk. Kuesioner diberikan kepada 20 pelanggan, wawancara terhadap 3 pelanggan serta analisis terhadap 93 komentar pada iklan digital mengenai contactless delivery di Instagram resmi KFC Indonesia. Dapat diambil kesimpulan jika program contactless delivery KFC disukai atau dinilai baik oleh partisipan. Partisipan berpendapat jika program contactless delivery KFC ini bermanfaat untuk dicoba dalam kondisi COVID-19. Hal ini dikarenakan mereka menganggap bahwa dengan menggunakan program ini dapat membantu dalam pencegahan penyebaran COVID-19, serta tentu memenuhi kebutuhan dasar manusia yaitu makan dalam kondisi COVID-19 dengan aman dan nyaman.
\end{abstract}

Keywords:

Contactless delivery;

COVID-19; Customer satisfaction; and Pandemic.

Korespondensi Penulis:

Novika Grasiaswaty

Email:

Novika.grasiaswaty88@gmail.com

\section{Abstract}

This study is about evaluating customer satisfaction with innovation products during the Covid-19 pandemic, namely contactless delivery conducted by KFC Indonesia. The research uses mix-method with quantitative and qualitative approaches. Data collected with three different way: a questionnaire to consumers who have used this product, in-depth interviews with customers and evaluation of digital advertising related to the product. The questionnaire was given to 20 customers, interviews with three customers and an analysis of 93 comments on digital advertisements regarding contactless delivery on KFC Indonesia's official Instagram. Conclusions can be drawn if the KFC contactless delivery program is favoured or rated well by the participants. Participants argued that the KFC contactless delivery program was useful to try in COVID-19 conditions. They consider using this program can help in preventing the spread of COVID-19, and meet the basic human needs of eating in COVID-19 conditions safely and comfortably. 


\section{Pendahuluan}

Kentucky Fried Chicken (KFC) pertama kali didirikan pada tahun 1930 oleh Colonel Harland Sanders (lahir pada 9 September 1890) pada usia 65 tahun. KFC merupakan salah satu bisnis terbesar global industri pelayanan makanan dan secara luas dikenal di seluruh dunia sebagai wajah Colonel Sanders. Saat ini Kolonel telah menyebarkan industrinya lebih dari 80 negara di seluruh dunia (Chaplinnn, 2013).

Setelah start-up luar biasa pada tahun 1952, Kolonel meyakinkan dirinya selama sisa hidupnya kepada usaha waralaba ayam. Untuk menyebarkan resepnya yang terkenal, ia membentang negara di mobilnya dari usaha kecil di Kentucky untuk memasak dengan ayam untuk pemilik restoran dan karyawannya. Kolonel membuat kesepakatan dengan pembentukan, mengatakan bahwa mereka akan membayar satu sen untuk setiap ayam mereka dijual di restoran mereka (Chaplinnn, 2013).

Pada tahun 1964, tidak sedikit restoran setuju dengan kesepakatan itu. Kolonel telah mendirikan lebih dari enam ratus outlet waralaba di Amerika Serikat, Kanada dan outlet pertamanya di Inggris. Juga pada tahun 1964, Colonel Sanders memutuskan untuk menjual bunga di Amerika Serikat perusahaan untuk perubahan kecil (hanya US \$ 2 juta) untuk faksi kecil investor, seperti John Y. Brown Jr, Gubernur Kentucky dari tahun 1980 sampai 1984. Namun, Colonel Sanders terus menjadi juru bicara publik KFC dan pada tahun 1976, ia diangkat menjadi kedua di dunia selebriti paling diidentifikasi oleh survei independen (Chaplinnn, 2013).

PT Fastfood Indonesia Tbk. ialah pemilik tunggal waralaba KFC di Indonesia, didirikan oleh Gelael Group pada tahun 1978 sebagai pihak pertama yang mendapat waralaba KFC di Indonesia. Perseroan memulai operasi restoran pertamanya pada bulan Oktober 1979 di Jalan Melawai, Jakarta, dan telah sukses. Kesuksesan outlet ini kemudian dibuntuti dengan pen- dahuluan outlet-outlet selanjutnya di Jakarta dan ekspansi area jangkauan hingga ke kotakota besar di Indonesia, antara lain Bandung, Semarang, Surabaya, Medan, Makassar, dan Manado. Keberhasilan yang terus diraih dalam pengembangan brand menjadikan KFC sebagai bisnis waralaba cepat saji yang dikenal luas dan berpengaruh di Indonesia (Sutarsa, 2019). Keberhasilan ini juga dapat dilihat dari semakin bertambahnya jumlah gerai KFC yang dibuka, dari awal pertama hanya satu gerai sampai saat ini terdapat 689 gerai KFC yang tersebar di 163 kota atau kabupaten di Indonesia.

Semenjak awal bulan Maret 2020, terjadi perubahan yang dirasakan masyarakat Indonesia pada kehidupan hariannya dikarenakan adanya epidemi virus corona atau COVID-19. Salah satu perubahannya berupa imbauan pemerintah agar masyarakat menjaga jarak dan tetap tinggal di rumah, dalam rangka usaha pencegahan penularan COVID-19, pemerintah mengimbau masyarakatnya untuk menjaga jarak dan tetap tinggal di rumah.

Dengan adanya imbauan untuk menjaga jarak dan tinggal di rumah tentu saja memberi efek yang drastis pada berbagai sektor dalam kehidupan. Salah satu sektor yang terkena dampaknya adalah makanan cepat saji KFC, PT Fast Food Indonesia Tbk (FAST). Terfokus pada aktivitas operasional, KFC mengalami penurunan nilai penjualan dan jumlah transaksi yang mempengaruhi perputaran khas perusahaan dan adanya perubahan pola konsumsi masyarakat yang dikarekanan tekanan COVID-19, menurut seorang Manajemen FAST (Saleh, 2020).

KFC melakukan berbagai cara dalam menghadapi COVID-19, salah satunya adalah dengan contactless delivery, yaitu pengiriman makanan ke rumah tanpa adanya kontak langsung. Program contactless delivery ini tentu saja disebarluaskan melalui berbagai media contohnya pada web resmi KFC (kfcku.com), Youtube (kfcindonesia), instagram (KFC indo- 
nesia), twitter (@KFCINDONESIA), face-book (KFC), dan aplikasi (KFCKU).

Dalam masa pandemi model layanan contactless delivery menjadi bagian penting (Farr et al., 2020; dan Zhao \& Bacao, 2020). Dalam bisnis makanan model layanan contactless delivery telah menjadi salah pilihan bagi konsumen. Perusahaan dan konsumen akan melakukan adaptasi baru, dengan menggunakan contactless delivery (Diebner, Silliman, Ungerman, \& Vancauwenberghe, 2020; Yuchen, 2020; Emmanueli et al., 2020; Ota, Sangita Ray, \& Kumar, 2020; dan Pavlović, Banjanin, Vukmirović, \& Vukmirović, 2020)

Penelitian ini mencoba untuk melihat program contactless delivery dari sudut pandang Stimulus Organism Response Model (SOR) yang dikembangkan oleh Mehrebian dan Russel (Arviansyah, dkk. 2018). Berda-sarkan SOR ini terdapat tiga komponen yang dapat mempengaruhi perilaku membeli, yaitu Vlogger Related Factors (Physical Attractiveness, Social Attractiveness, dan Attitude Homophily), Task Related Factors (Imformativeness), dan Mood Related Factors (Entertaiment, Creativity, dan Video Production Quality).

Program contactless delivery yang ditayangkan pada iklan tentu saja akan memberikan stimulus yang akan ditangkap masyarakat dengan berbeda-beda. Berdasarkan pertimbangan kelompok pada iklan tersebut yang secara signifikan dapat mempengaruhi perilaku membeli pada komponen Task Related Factors (Imformativeness), dimana masyarakat mendapatkan suatu keuntungan atau manfaat ketika membeli KFC dengan menggunakan program contactless deliver. Selain itu adanya komponen Vlogger Related Factors (Attitude Homophily), dimana dengan keadaan COVID19 masyarakat maupun karyawan KFC yang melihat iklan tersebut merasa terhubung atau memiliki kesamaan dengan apa yang ada di iklan, sehingga dapat beroengaruh dalam perilaku membeli.
Peneliti melihat program contactless delivery berdasarkan salah satu cara pemasaran, yaitu marketing mix (bauran pemasaran). Kotler dan Amstrong (2004) mendefinisikan bauran pemasaran sebagai seperangkat alat pemasaran yang dibuat dan dapat dikendalikan perusahan untuk menghasilkan tanggapan yang diinginkan di pasar sasaran (Khaeriyyah, 2010). Dalam Widjaya (2017), marketing mix didefinisikan sebagai variabel-variabel yang akan diawasi dan disusun oleh perusahaan untuk memuaskan kelompok yang ditarget. Bauran pemasaran produk, harga, promosi, dan distribusi adalah strategi perusahaan untuk mewujudkan tujuannya untuk berusaha di pasar (Widjaya, 2017).

\section{Metode Penelitian}

Untuk mengetahui kepuasan pelanggan pada program contactless delivery KFC, peneliti menggunakan metode kuantitaif dan kualitatif. Pada metode kuantitatif dilaukan analisis terhadap komentar pada postingan iklan di Instagram dan dilakukan penyebaran kuesioner kepuasan pelanggan dengan skala likert, sedangkan pada metode kualitatif akan dilakukan wawancara semi-terstruktur. (Pertanyaan kuesioner dan pedoman wawancara).

Kuesioner penelitian dikembangkan dengan mengacudari Nofriyanto (2018). Penggunaan sumber atau acuan ini peneliti lakukkan dengan upaya memberi gambaran bagi peneliti dalam membuat kuesioner. Setelah memiliki acuan ini, kuesioner dibuat dengan adanya penesuaian terhadap produk peneliti yaitu program contactless delivery KFC.

Kuesioner dibagi menjadi empat dimensi atau bagian, dimana peneliti berharap bagianbagian ini dapat menggambarkan kepuasan pelanggan pada program program contactless delivery KFC. Dimensi atau bagiannya adalah harga, praktis, kualitas, dan waktu. Dimensi harga menggambarkan tingkatan kepuasan target pasar terhadap harga makanan atau minuman dan juga biaya kirim. Dimensi praktis adalah tingkatan kemudahan atau kesulitan 
dari proses penggunaan program, dimana praktis menggambarkan adaanya kemudahan atau manfaat akan produk. Dimensi kualitas menggambarkan gambaran atau persepsi target pasar terhadap program contactless delivery KFC. Dimensi waktu ialah kehematan ataupun kecepatan waktu yang digunakan dalam pelaksanaan program contactless delivery KFC.

Dalam pembuatan kuesioner peneliti mendapatkan suatu kesulitan dikarenakan program contactless delivery KFC. Dimana peneliti menyadari bahwa sulit untuk menemukan partisipan yang sudah menggunakan program ini. Dalam mengatasi hal ini peneliti memiliki dua solusi yaitu: 1) peneliti sebagai anggota peneliti memesan makanan menggunakan program contactless delivery KFC, dan anggota keluarga peneliti akan menjadi partisipan dalam kuesioner dan wawancara. Lalu setelah peneliti menelepon cabang KFC, ditemukan bahwa tidak semua cabang KFC melakukan program ini. Hal ini menjadi hambatan dalam mencari cabang KFC yang melalukan program. 2) peneliti menunjukan iklan video akan program contactless delivery KFC pada partisipan sebelum mengisi kue-sioner dan wawancara. Setelah melihat iklan, kuesioner dan pertanyaan wawancara yang diberikan akan dalam bentuk pendapat atau persepsi partisipan terhadap program contactless delivery KFC.

Setelah pertimbangan peneliti, peneliti memutuskan melakukan pilihan kedua dalam pembuatan kuesioner dan wawancara. Hal ini peneliti putuskan karena peneliti ingin mengetahui pendapat atau persepsi partisipan dan apakah ia sekiranya akan merasa mau dan puas akan program contactless delivery KFC. Jumlah responden dalam penelitian sebanyak 20 pelanggan.

\section{Hasil dan Pembahasan}

\section{Hasil}

\section{Karakteristik Responden}

Karakterisktik responden bervariasi. Responden terdiri 12 laki-laki dan 8 perempuan. Usia responden: 9 orang berumur $<20$ tahun, 8 orang berumur 21-30 tahun, dan 3 orang berumur $>50$ tahun. Sedangkan dari status responden yang masih melajang yaitu 17 orang dan 3 orang yang sudah berkeluarga (menikah dan memiliki anak). Tingkat pendidikan terakhir orang juga beragam, dimana 12 orang berpendidikan terakhir SMA atau sederajat, 3 orang berpendidikan SMP, 3 orang berpendidikan akhir S2/Magister dan 2 orang berpendidikan terakhir S1/ Sarjana. 17 orang merupakan pelajar /mahasiswa, 2 orang bekerja sebagai wiraswasta, dan 1 orang bekerja sebagai profesi. Sepuluh orang memiliki penghasilan $\leq \operatorname{Rp} 500.000,4$ orang berpenghasilan Rp1.000.000< sampai $\mathrm{Rp} 5.000 .000,2$ orang berpenghasilan $\mathrm{Rp} 500.000<$ sampai $\mathrm{Rp}$ 1.000.000, dan 2 partisipan berpenghasilan diatas $\operatorname{Rp} 10.000 .000$.

Berdasarkan kuesioner diketahui bahwa 12 dari 20 partisipan bertempat tinggal di daerah yang merupakan zona merah COVID-19. Dengan, 6 partisipan bertempat tinggal di Bekasi, 1 di Cempaka putih, 1 di Codet, 1 di Jakarta Utara, 1 di Tanggerang Selatan, 1 di Tanjung Priuk, dan 1 di Kelapa Gading.

Berdasarkan hasil penelitian terhadap responden terkait dengan program Contactless Delivery KFC Indonesia. Hasil penelitian disajikan pada tabel 1. Dimensi yang terkait dengan Contactless Delivery terdiri dari 4 dimensi.

Berdasarkan tabel 1 menunjukkan bahwa terkait dengan dimensi harga menunjukkan bahwa pelanggan merasa harga KFC dengan penggunaan jasa contactless delivery untuk menghemat biaya dibanding pergi ke gerai KFC menunjukkan, harga dengan menggunakan. Responden merasa harga KF dengan menggunakan jasa program contactless delivery relatif sama dengan yang ada di gerai. Biaya pengiriman dirasakan oleh pelanggan tidak memberatkan. Biaya Pengiriman untuk jasa contactless delivery sebesar $R p$ 12.000.

Hasil analisis terkait dengan dimensi praktis, maka jasa contactless delivery dirasakan sangat praktis bagi pelanggan. Hal ni terlihat dari respon pelanggan yang me-nyatakan bahwa program tersebut dapat membantu dapat membantu pelanggan untuk mengerjakan hal-hal lain. Transaksi dalam ketika me- 
nggunakan jasa contactless delivery membantu pelanggan. Pelanggan merasakan bahwa transaksi pembayaran dalam menggunakan jasa contactless delivery relatif dapat berjalan dengan mudah. Mayoritas pelanggan merasakan bahwa cara pemesanan dalam menggunakan jasa contactless delivery mudah.

Indikator untuk dimensi kualitas menunjukkan bahwa dalam pelaksanaan program jasa contactless delivery pelanggan yakin
KFC menjalankan dengan semaksimal mungkin. Hanya $20 \%$ pelanggan yang merasa tidak yakin. Pelanggan yakin bahwa menggunakan jasa contactless delivery sangat membantu dalam pencegahan COVID-19. Hal ini ditunjukkan dengan responden yang merasa sangat yakin dan yakin sebanyak $40 \%$ dan $50 \%$. Pelanggaan yakin bahwa makanan yang diantar menggunakan jasa contactless delivery kebersihan makanan dapat terjaga, $80 \%$.

Tabel 1

Distribusi Frekuesnsi Dimensi Contactless Delivery

\begin{tabular}{|c|c|c|c|c|c|c|c|c|c|}
\hline \multirow{2}{*}{ Dimensi } & \multirow{2}{*}{ Contactless Delivery } & \multicolumn{2}{|c|}{ SS } & \multicolumn{2}{|c|}{$S$} & \multicolumn{2}{|c|}{ TS } & \multicolumn{2}{|c|}{ STS } \\
\hline & & $\mathrm{F}$ & $\%$ & $\mathrm{~F}$ & $\%$ & $\mathrm{~F}$ & $\%$ & $\mathrm{~F}$ & $\%$ \\
\hline \multirow{3}{*}{ Harga } & Hemat Biaya & 1 & 5 & 15 & 75 & 3 & 15 & 1 & 5 \\
\hline & Kesesuaian Harga & 2 & 10 & 17 & 85 & 1 & 5 & 0 & 0 \\
\hline & Biaya Pengiriman Tidak Membebani & 1 & 5 & 11 & 55 & 7 & 35 & 1 & 5 \\
\hline \multirow{3}{*}{ Praktis } & Membantu Pekerjaan & 5 & 25 & 15 & 75 & 0 & 0 & 0 & 0 \\
\hline & Kemudahan Dalam Transaksi Pembayaran & 3 & 15 & 17 & 85 & 0 & 0 & 0 & 0 \\
\hline & Kemudahan dalam Pemesaanan & 4 & 20 & 16 & 80 & 0 & 0 & 0 & 0 \\
\hline \multirow{3}{*}{ Kualitas } & Pelaksanaan Program yg optimal & 2 & 10 & 14 & 70 & 4 & 20 & 0 & 0 \\
\hline & Membantu Dalam Pencegahan Covid-19 & 8 & 40 & 10 & 50 & 1 & 5 & 1 & 5 \\
\hline & Kebersihan Makanan Terjaga & 2 & 10 & 16 & 80 & 1 & 5 & 1 & 5 \\
\hline \multirow{3}{*}{ Waktu } & Kecepatan Pengantaran & 2 & 10 & 17 & 85 & 1 & 5 & 0 & 0 \\
\hline & Kehangatan Kondisi Makanan & 2 & 10 & 14 & 70 & 4 & 20 & 0 & 0 \\
\hline & Kecepatan Proses Pembayaran & 2 & 10 & 15 & 75 & 2 & 10 & 1 & 5 \\
\hline
\end{tabular}

Dimensi waktu untuk menggunakan jasa contactless delivery menunjukkan responden merasa pengantaran makanan dilakukan dengan cepat. Hal ini tampak $85 \%$ menyatakan cepat dan $10 \%$ menyatakan sangat cepat. Kondisi makanan yang diantar Ketika sampai pada pelanggan, pelanggan mersakan bahwa kondisinya masih hangat. Hal ini tentunya terkait dengan jarak. Namun demikian responden yang merasakan bahwa kondisi makanan masih segar mayoritas setuju. Kecepatan proses pembayaran, pelanggan merasakan bahwa proses pembayarannya dapat berjalan dengan cepat.

\section{Hasil Wawancara}

\section{Partisipan A}

Dalam kategori harga, partisipan A berpendapat bahwa ia akan menghemat biaya bensin dan waktu dengan menggunakan program contactless delivery KFC, ia juga menyatakan bahwa makanan dalam program dan

yang ada di gerai seharusnya memiliki harga yang sama, ia juga berpendapat bahwa harga biaya pengiriman relatif tergantung individu yang membelinya

Dalam kategori kepraktisan, partisipan A setuju bahwa program contactless delivery KFC dapat membuat individu dapat melakukan kegiatan lain, ia juga menilai bahwa dalam transaksi pembayaran dan penerimaan makanan tidak sulit, serta pemesanan makanan juga tidaklah menyulitkan karena hanya diperlukan menelepon saja.

Dalam kategori kualitas, partisipan A berpendapat bahwa ia tidak yakin dengan realisasi pelaksanaan program contactless delivery dapat berjalan dengan maksimal, namun ia percaya bahwa dengan program ini dapat membantu dalam kondisi COVID-19 dan juga kebersihan makanan akan lebih terjaga. 
Dalam kategori waktu, partisipan berpendapat bahwa makanan akan sampai tidak lama apabila tidak macet dan jaraknya dekat, dan juga makanan akan masih terasa hangat walaupun tidak panas saat sampai ke rumah, dan partisipan A juga menyatakan bahwa transaksi pembayaran dan penerimaan makanan dapat berjalan dengan cepat dan tidak merepotkan.

Partisipan A menyatakan bahwa ia mau mencoba program contactless delivery. Lalu apabila tidak ada hal yang tidak menyenangkan terjadi partisipan A mau memesan makanan melalui program ini lagi.

\section{Partisipan B}

Dalam kategori harga, partisipan B berpendapat bahwa ia lebih memilih untuk pergi ke gerai KFC-nya langsung dikarenakan jarak dari rumahnya ke gerai KFC relatif dekat. Jika ia menggunakan contactless delivery, maka ia akan membayar biaya pengiriman yang mana biaya pengiriman lebih mahal daripada membeli secara langsung di gerai KFC. Ia juga mengatakan bahwa makanan dalam program contactless delivery dan di gerai KFC seharusnya memiliki harga yang sama. Ia berpendapat bahwa dengan biaya pengiriman Rp12.000 sangatlah mahal. Ia lebih memilih membelinya lewat ojek online karena disana sering terdapat promo yaitu gratis biaya pengiriman.

Dalam kategori kepraktisan, partisipan B setuju bahwa program contactless delivery KFC dapat membantunya untuk mengerjakan halhal lain. Ia juga menilai bahwa dalam transaksi pembayaran dan penerimaan makanan tidak sulit. Ia dapat melakukan pembayaran setelah makanan tersebut sampai di rumahnya. Untuk pemesanan makanan juga menurutnya cukup menyulitkan dikarenakan ia harus mempunyai pulsa untuk menelepon ke gerai KFC yang terdapat program contactless delivery.

Dalam kategori kualitas, partisipan A berpendapat bahwa ia tidak yakin dengan realisasi pelaksanaan program contactless delivery dapat berjalan sesuai dengan iklan KFC di instagram. Kemudian ia percaya bahwa dengan menggunakan jasa contactless delivery sangat membantu dalam pencegahan COVID19 dan kebersihan makanan dapat terjaga dengan baik.

Dalam kategori waktu, partisipan mengatakan bahwa makanan yang dipesannya lewat program contactless delivery akan sampai tidak lama jika jarak dari gerai KFC ke rumahnya dekat sehingga makanan yang di antarkan masih hangat saat sampai ke rumahnya. Kemudian ia mengatakan bahwa transaksi pembayaran dan penerimaan makanan dapat berjalan dengan cepat dan tidak merepotkan.

Partisipan B mengatakan bahwa ia akan mencoba memesan makanan menggunakan program contactless delivery. Jika setelah dia memesan makanan melalui program contactless delivery KFC tidak ada hal yang tidak menyenangkan atau merasa puas dengan layanan tersebut, maka ia mau memesan makanan melalui program ini lagi.

\section{Partisipan C}

Dalam kategori harga, partisipan C kurang memperhatikan dalam menggunakan program contactless delivery karena menurut partisipan $C$ jika ingin mengkonsumsi ayam gurih KFC harus pergi langsung ke gerai terdekat. Menurutnya, ke gerai KFC baginya salah satu destinasi untuk berpergian bersama orang terdekat maupun keluarga sehingga untuk memesan untuk mengokunsumsinya di rumah dengan cara pakai jasa kurir itu tidak biasa baginya dan juga harus mewajibkan membayar lebih.

Dalam kategori kepraktisan, Walaupun menurut partisipan tidak biasa delivery order, tetap perlu untuk menggunakan program tersebut karena mampu membantu mengerjakan hal yang lainnya jika sedang sibuk atau kurang banyak waktu apabila harus memasak terlebih dahulu. Kemudahan juga dalam transaksi pembayaran karena langsung diantar ke rumah tanpa harus menunggu dan mengantri digerainya.

Dalam kategori kualitas, menurut partisipan $\mathrm{C}$ mungkin sudah cukup baik karena dari pengalamannya jika ia sedang dalam 
perjalanan melihat kurir yang mengirim makanannya dengan sangat hati-hati untuk menjaga makanannya tersebut. Lalu, jika dikaitkan dengan adanya wabah COVID-19 sekarang ini menjadi mudah dan aman karena tidak harus bertemu banyak orang dan sedikit kemungkinannya untuk bisa terkena virus tersebut.

Dalam segi waktu, partisipan merasa memang harus lebih bersabar untuk menunggu pengiriman makanannya datang apalagi disaat ia sudah tidak tertahan karena rasa laparnya. Dari pengalaman subjek, lebih dari 2 kali disaat memesan delivery order yang rata rata cukup lama sehingga saat makanan datang menurutnya tidak masalah tingkah kehangatannya.

Menurut partisipan $\mathrm{C}$, ia akan menggunakan jasa ini jika sangat memang diperlukan dengan didukung waktu yang kurang banyak dan pekerjaan yang sedang dikerjakananya belum terselesaikan misalnya. Lalu, dari pengalaman yang sudah ada ada kemungkinan ia ingin memesannya kembali jika dihadapkan dengan situasi tersebut.

\section{Analisis Komentar Pada Postingan Iklan di Instagram}

Pada iklan di Instagram terdapat 93 komentar yang ditinggalkan target pasar. Berdasarkan komentar-komentar ini, peneliti mengelompokkannya ke dalam sembilan kelompok berbeda.

Pertama, Mendukung program contactless delivery. Pengelompokan pertama ini merupakan kelompok komentar yang mendapat jumlah komentar dari taget pasar terbanyak, yaitu 17 komentar. Beberapa con-toh dari kelompok komentar ini adalah: 1) Kalau caranya bersih gini jadi nyaman order, 2) Mantap ya KFC hebat. Semoga tetap lancar. Semua karyawan KFC diberi sehat selalu, 3) Hebat! Akhirnya KFC mendukung program \#dirumahaja.

Kedua, Tidak mempercayai pada saat praktik akan sama seperti iklan. Komentar dari responden: 1) Teori mah tjakep beda kalau sama di lokasi kenyataannya. Gua sebagai mantan KFC menurut gua agak ribet, 2) Yakin prakteknya bakal kayak gitu? Manusiamanusia +62 loh dimari.

Ketiga, kritik mengenai proses contactless delivery pada iklan (tidak menggunakan sarung tangan dari awal). Komnetar dari responden: 1) Kenapa gak dari awal pakai sarung tangan, dari awal masukin produknya ke dalam tas? Harusnya petugasnya dari awal menggunakan sarung tangan, 2) Lebih aman lagi masukinnya pakai sarung tangan juga.

Keempat, menanyakan wilayah KFC yang memberlakukan program contactless delivery. Komentar dari responden: 1) Di KFC Bireuen Aceh berlaku gak min order lewat telepon gini?, 2) Bisa kirim ke area Kunjang kabupaten Kediri?.

Kelima, menanyakan biaya pengiriman/ berkomentar biaya terlalu mahal. Komentar dari responden: 1) KFC Timika ongkos kirimnya mahal banget. 2) Ada ongkirnya?

Keenam, terkait dengan jarak tempuh pengiriman program contactless delivery. Komentar pelanggan: Ada telepon kesini min, tapi dijawab gak bisa antar karena lebih dari 5 $\mathrm{km}$. padahal dulu awal tinggal masih bisa antar dari KFC yang Pamulang Square.

Ketujuh, meminta promo melalui program contactless delivery. Komentar pelanggan: 1) Free ongkir dong min, 2) Sesekali di gratisin dong, dengan situasi seperti ini sangat membantu ya kan.

Delapan, terkait dengan complaint karena salah pesanan yang diterima. Komentar pelanggan: Berharap \#dirumahaja nunggu pesanan ternyata kecewa. Pesan mocca float di KFC Ramayana Palembang tapi dikasih tanpa ice cream.

Kesembilan, terkait dengan komentar tidak jelas (syutingnya dimana, kenal dengan orang di iklan, tag orang lain,). Komentar pelanggan: 1) Modelnya kayak gua kenal, 2) Syuting dimana ini?

Jika dilihat dari pengelompokkan dan jumalahnya masing-masing komentar, kelompok berpendapat bahwa komentar pada postingan iklan instagram tidak memberikan gambaran akan kepuasan pelanggan dari program contactless delivery. Diperlukan data lain yang lebih valid dan reliabel contohnya data 
pembelian menggunakan program contac-tless delivery dan perbandingan penghasil-annya dengan sebelum diberlakukan progam contactless delivery.

\section{Analisis Hasil Pengambilan Data}

Pertanyaan kuesioner peneliti berikan dalam bentuk pertanyaan favorable, yaitu pertanyaan yang baik atau adanya gambaran positif terhadap program contactless delivery KFC. Kuesioner dibagi menjadi empat dimensi atau bagian, dimana kelompok berharap bagian-bagian ini dapat menggambarkan kepuasan pelanggan pada program program contactless delivery KFC. Dimensi atau bagiannya adalah harga, praktis, kualitas, dan waktu. Dimensi harga menggambarkan ting-katan kepuasan target pasar terhadap harga makanan atau minuman dan juga biaya kirim. Dimensi praktis adalah tingkatan kemudahan atau kesulitan dari proses penggunaan program, dimana praktis menggambarkan adaanya kemudahan atau manfaat akan produk. Dimensi kualitas menggambarkan gambaran atau persepsi target pasar terhadap program contactless delivery KFC. Dan dimensi waktu ialah kehematan ataupun kecepatan waktu yang digunakan dalam pelaksanaan program contactless delivery KFC.

Dalam perhitungan kuantitas kuesioner peneliti memberikan point pada tiap pilihan jawaban, dimana pilihat sangat tidak setuju (1 point), tidak setuju (2 point), setuju (3 point), dan sangat tidak setuju (4 point). Tiap item apabila setiap partisipan menjawab sangat setuju total point akan menjadi 80 point (4 point x 20 partisipan), total point tiap dimensi 240 point (80 point $\times 3$ item) dan keseluruhan 960 point (80x12 item). Dimana untuk pengukuran kepuasannya, total point yaitu 960 point, akan dibagi menjadi 4 kategori. Dimana keempat kategori itu menggambarkan kepuasan atau penilaian partisipan terhadap produk. Kategorinya adalah sangat tidak suka (point 0-240), tidak suka (point 241-480), suka (point 481-720), dan sangat suka (point 721-960).

Total point pada dimensi harga (item 12-3) yaitu 184 point dari 240 point total per- dimensi. Pada dimensi praktis jumlah pointnya adalah 192 point dari 240 point total perdimensi. Dimensi ketiga, yaitu dimensi kualitas memiliki total point 173 point dari 240 point total per-dimensi. Dan dimensi waktu memiliki jumlah 177 point dari 240 point total perdimensi. Total point seluruh item adalah 731 point dari 960 point total.

Para partisipan lebih banyak memilih pilihan 'setuju' pada tiap item kuesioner, dimana pemilihan pilihan 'setuju' paling sedikit ialah 11 partisipan dari 20 partisipan pada satu item. Hal ini menunjukan bahwa lebih dari 50\% partisipan memilih setuju, sehingga dapat dikatakan program contactless delivery KFC dapat dibilang disukai atau dinilai baik oleh partisipan. Selain itu, total point seluruh item adalah 731, diamana tergolong dalam kategori sangat suka (point 721-960) dalam penggambaran kepuasan atau penilaian partisipan terhadap produk.

\section{Analisis Hasil Wawancara}

Dari ketiga partisipan yang sudah kelompok wawancarai, menunjukkan bahwa partisipan menyetujui jika menggunakan jasa delivery dengan situasi tertentu seperti sedang mengerjakan pekerjaan yang harus terselesaikan atau jarak rumah yang cukup jauh karena bagaimanapun juga partisipan merasa cukup praktis dalam memesan maupun dalam melakukan pembayarannya. Tetapi, jika merasa situasi tersebut tidak mereka rasakan maka partisipan lebih memilih untuk ke gerai KFC dan partisipan juga menganggap bahwa kualitas yang ada pada program KFC tersebut sudah cukup baik dan maksimal yang diambil dari pengalaman partisipan sampai saat ini walaupun memang harus bersabar demi menunggu pengiriman makanan yang datang kerumah. Gerai KFC yang sudah ada dimanamana dan adanya ojek online yang terkadang memudahkan partisipan untuk memesan makanan tersebut dengan harga pengiriman yang cukup relatif lebih murah dari program contactless delivery KFC sehingga partisipan menganggap harga yang sudah ditarifkan terbilang cukup mahal. 
Jika dikaitkan dengan wabah COVID 19 sekarang ini, partisipan merasa sangat membantu karena bisa menjauhkan partisipan dari virus yang ada karena partisipan hanya diam dirumah dan makanan akan siap dikirimkan langsung kerumah. Partisipan berasumsi jika memesan makanan melalui program contactless delivery KFC tidak ada hal yang tidak menyenangkan atau merasa puas dengan layanan tersebut, maka ia mau memesan makanan melalui program ini lagi.

Oleh karena itu, berdasarkan wawancara terhadap tiga partisipan dapat diketahui bahwa program contactless delivery KFC ini bermanfaat untuk dicoba dalam kondisi COVID19. Hal ini dikarenakan mereka menganggap bahwa dengan menggunakan program ini dapat membantu dalam pencegahan penyebaran COVID-19, serta tentu memenuhi kebutuhan dasar manusia yaitu makan dalam kondisi COVID-19 dengan aman dan nyaman.

\section{Simpulan dan Saran}

\section{Simpulan}

Kesimpulan dari analisis yang peneliti dapatkan dari salah satu media sosial yaitu instagram yang melalui postingan iklan yang ada pada akun resmi KFC menghasilkan bahwa komentar yang ada pada iklan di instagram tersebut tidak memberikan gam-baran akan kepuasan pelanggan mengenai program contactless delivery. Sehingga diperlukan data lain yang lebih valid dan reliabel seperti data pembelian perbandingan dari sebelum dan sesudah diberlakukan contactless delivery. Kelompok menggunakan data dari kuesioner dan hasil wawancara sebagai pelengkap data mengenai program contactless delivery. Jika dilihat dari kuesioner, menun-jukan bahwa lebih dari $50 \%$ partisipan pada setiap item kuesioner memilih setuju, sehingga dapat dikatakan program contactless delivery KFC disukai atau dinilai baik oleh partisipan. Berdasarkan wawancara terhadap tiga par-tisipan dapat diketahui bahwa program contactless delivery KFC ini bermanfaat untuk dicoba dalam kondisi COVID-19. Hal ini karena mereka menganggap bahwa dengan mengguna- kan program ini dapat membantu dalam pencegahan penyebaran COVID-19, serta tentu memenuhi kebutuhan dasar manusia yaitu makan dalam kondisi COVID-19 dengan aman dan nyaman.

\section{Saran}

Digital marketing yang KFC lakukan untuk program contactless delivery sudah dilakukan dengan baik. Dimana mereka memperkenalkan langkah-langkah akan pelaksanaan program ini ketika berjalan. Hal ini menjadi informasi penting bagi pelanggan agar mereka percaya dan menggunakan program contactless delivery KFC. Namun, peneliti berpendapat bahwa iklan ini masih menimbulkan keraguan akan keberlangsungan program pada situasi nyatanya. Oleh ka-rena itu, seperti yang peneliti sarankan diatas harus adanya suatu tindakan yang membuat target pasar yakin akan pelaksanaan program contactless delivery di kehidupan nyatanya. Sebelum dilakukan tindakan (yang kelompok sarankan), lebih baik jika adanya iklan mengenai tindakan ini sendiri, sehingga target pasar mengetahui bahwa pihak KFC mela-kukan pengawasan yang ketat akan keber-langsungan program program contactless delivery. Selain itu, hasil dari kuesioner kepuasan pelanggan juga dapat ditunjukan kepada umum, sehingga membuat rasa percaya pada target pasar akan program contactless delivery.

\section{Daftar Pustaka}

Chaplinnn. (2013). Sejarah Berdirinya KFC dan Perkebangannya Kini. Diakses pada tanggal 13 April 2020 dari https://www.kaskus.co.id/thread/5127 19cc1dd719772600000a/sejarahberdirinya-kfc-dan-perkebangannyakini/

Arviansyah, Dhaneswara, A. P., Hidayanto, A. N., \& Zhu, Y. Q. (2018). Vlogging: Trigger to Impulse Buying Behaviors. In PACIS (p. 249).

Diebner, R., Silliman, E., Ungerman, K., \& Vancauwenberghe, M. (2020). Adapting 
customer experience in the time of coronavirus. McKinsey $\mathcal{E}$ Company, (April), 1-7. Retrieved from https://www.mckinsey.com/businessfunctions/marketing-and-sales/ourinsights/adapting-customer-experiencein-the-time-of-coronavirus

Emmanueli, C., Maechler, N., Jain, N., Thomas, A., Malfara, D., Moritz, S., ... Nelson, A. (2020). Elevating customer experience excellence in the next normal. McKinsey $\mathcal{E}$ Company, (May), 1-6. Retrieved from https://www.mckinsey.com/businessfunctions/operations/ourinsights/elevating-customer-experienceexcellence-in-the-next-normal

Farr, M., Hu, S., Lindsey, S., Ripple, S., Srikanth, S., \& Webb, C. (2020). Coronavirus Pandemic Implications.

Khaeriyyah, N. (2010). Analisis Pengaruh Promosi Terhadap Positioning Restoran Fast Food Merek Kentucky Fried Chicken (KFC) di Kota Bogor. Skripsi. Teknologi Pertanian. Departemen Teknologi Industri Pertanian. Institut Pertanian Bogor. Bogor.

Nofriyanto. (2018). Kuesioner Penelitian: Pengaruh online Food Delivery (OFD), Kualitas Produk, Halal Awareness Terhadap Kepuasan Pelanggan dan Loyalitas Pelanggan Di Usaha Kuliner di Yogyakarta. Diakses pada 16 April 2020 pada

https://dspace.uii.ac.id/bitstream/hand le/123456789/11734/13.\%2007.1\%20Lam pi-

ran $\% 201 \% 20$ Kuesioner.pdf?sequence $=11$ \&isAllowed $=y$

Ota, R., Sangita Ray, S., \& Kumar, R. (2020). A Study on the Indian Consumer mindset towards online shopping during the pandemic period: A special reference to Flipkart. Science, Technology and Development, 9(7), 197-204.

Pavlović, Z., Banjanin, M., Vukmirović, J., \& Vukmirović, D. (2020). Contactless Ict Transaction Model of the Urban Transport Service. Transport, 0(0), 1-11. https://doi.org/10.3846/transport.2020. 12529

Saleh. (2020). RI Lawan Corona, Gerai KFC Mulai Berdampak. dalam cnbcindonesia.com diakses pada Selasa, 14 April 2020.

Sutarsa. (2019). Sejarah berdirinya KFC dan Pekembangannya di Indonesia. Diakses pada tanggal 13 April, 2020 dari https://www.vlikoo.com/2019/04/sejar ah-berdirinya-kfc-danperkembangannya-di-indonesia.html

Widjaya, P.G. (2017). Analisis Segmenting, Targeting, Positioning dan Marketing Mix pada PT.Murni Jaya. AVOGRA Vol.5, No.1. Surabaya: Universitas Kristen Petra.

Yuchen, G. (2020). Factors Affecting Online Food Quality Control among Delivers in Delivery Process in Malaysia. IOSR Journal of Business and Management, 22(5), 26-29. https://doi.org/10.9790/487X2205012629

Zhao, Y., \& Bacao, F. (2020). What factors determining customer continuingly using food delivery apps during 2019 novel coronavirus pandemic period? International Journal of Hospitality Management What factors determining customer continuingly using food delivery apps during 2019 novel coronavirus pandemic period? International Journal of Hospitality Management, 91(September), 102683. https://doi.org/10.1016/j.ijhm.2020.102 683 